\title{
mtDNA diversity and phylogeography of some Turkish native goat breeds"
}

\author{
Bengi ÇINAR KUL ${ }^{1}$, Okan ERTUĞRUL $^{1}$ \\ ${ }^{1}$ Department of Genetics, Faculty of Veterinary Medicine, University of Ankara, Turkey.
}

\begin{abstract}
Summary: Mitochondrial DNA is one of the most preferred markers being used in phylogenetic studies in domestic animals due to its unique features. In this study, the mitochondrial DNA control region was analyzed in Angora, Honamli, Kilis, Hair and Norduz goat breeds $(n=252)$ to reveal diversity of mitochondrial DNA, differentiation of goat breeds, and relevance between genetic differentiations and geographic distributions. Based on the performed analysis methods, three different haplogroups; A, D and G were determined for breeds studied. Two duplication insertions (77bp) were observed in two animals from different breeds. In comparison with goat breeds throughout the world, the haplotype number, higher nucleotide and haplotype diversity values ( $\pi=0,02100, \pm 0,00073$ and $\mathrm{H}=0,9982, \pm 0,0006$ respectively) for goat breeds studied in the present study, indicate that Turkey has been situated in a central position during the domestication process of the goat specie. Based on our haplotype sharing detection results, Kilis and Norduz breeds, which are known as crossbreeds of Hair goats, do not share haplotypes with Hair goats, thus, the history of these breeds should be further investigated. The results of the study also gave hints that conservation flocks should be promoted immediately in local breeders for Norduz breed, which is under risk of extinction, along with a controlled mating program to prevent loss of genotypes. In this study, an inexpensive novel method based on PCR- RFLP was introduced to determine G haplotype, a unique haplotype to Fertile Crescent regions.
\end{abstract}

Key words: Genetic diversity, mtDNA, phylogenetics, Turkish native goat breeds.

\section{Bazı Türkiye yerli keçi ırklarının mtDNA çeşitliliği ve filocoğrafyası}

Özet: Mitokondrial DNA, evcil hayvanların filogenetik çalışmalarında en fazla tercih edilen belirteçlerden birisidir. Bu çalışmada, Ankara, Honamlı, Kilis, Kıl ve Norduz keçi ırklarının (n=252) mitokondrial DNA çeşitlilikleri, ırklar arası farklılıkları ve bu farklılıkların coğrafik yerleşimleri ile olan ilişkisinin ortaya konulması amacıyla mitokondrial DNA kontrol bölgesi analiz edilmiştir. Analiz sonuçlarına göre iki farklı ırktan iki bireyde 77bp'lik tekrarlama mutasyonu belirlenmiştir. İncelenen ırklarda A, D ve G haplogrupları olmak üzere üç farklı haplogrup belirlenmiştir. Elde edilen yüksek haplotip sayısı, yüksek nükleotid $(\pi=0,02100$, $+/-0,00073)$ ve haplotip çeşitliliği $(H=0,9982,+/-0,0006)$ değerleri dünya keçi irklarıyla karşılaştırıldığında, Türkiye'nin, keçilerin evciltilmesinde merkezi bir konumda olduğu düşünülmektedir. Haplotip paylaşımları göz önüne alındığında; Kıl keçisi melezi oldukları bilinen Kilis ve Norduz keçi ırklarının Kıl keçisiyle hiç haplotip paylaşmıyor olmaları ırkların tarihinin daha iyi araştırılmasının gerekliliğini ortaya koymuştur. Çalışmanın sonuçları aynı zamanda, yok olma açısından ağır tehdit altında olan Norduz keçi ırkı için acil olarak halk elinde koruma sürüleri oluşturulması ve mevcut genotiplerin kaybının önüne geçilebilmesi için kontrollü birleştirmelerin yapılması gerekliliğini ortaya koymaktadır. Bu çalışma sayesinde Verimli Hilal bölgesine özgü olan $\mathrm{G}$ haplogrubunun daha az maliyetle belirlenebilmesi için PZR-RFLP'ye dayanan yeni bir yöntem ortaya konulmuştur.

Anahtar kelimeler: Filogenetik, genetik çeşitlilik, mtDNA, Türkiye yerli keçi ırkları.

\section{Introduction}

Domestication of the animals, considered as one of the most important milestones of modern human life, began about 11,000 years ago in the Neolithic age on the lands known as "Fertile Crescent". The four livestock species were given priority in the domestication course: cattle, pig, sheep and goat (Zeder, 2008). In the fields of domestication history and phylogeography, mitochondrial DNA (mtDNA) has been one of the most preferred markers since it has some advantages such as capacity to demonstrate geographic distribution of species, higher evolutionary rate compared to genomic DNA, maternal inheritance, and absence of recombination (Wu et al., 2009). In comprehensive studies, which are mainly focused on the goat domestication, cytochrome $b$ and Dloop regions located on mtDNA have been frequently used (Luikart et al., 2001; Naderi et al., 2007). In such studies, the necessity of more sample analyses from

\footnotetext{
* This paper has been summarized from the part of $\mathrm{PhD}$ thesis entitled "Mitochondrial DNA diversity and phylogeography of Turkish native goat breeds" and supported by grants from TUBITAK, Turkey (KAMAG-106G005, TURKHAYGEN-1).
} 
domestication centers such as Turkey has been emphasized since molecular studies carried out on domestic livestock animals have obviously revealed that these species have distributed to European zones across Anatolia (MacHugh and Bradley, 2001; Naderi et al., 2008; Zeder, 2008).

Turkish native goat breeds, have an important position in domestication history, besides they are valuable genetic resources for the ecosystem and economy. Uptodate, there is not much comprehensive and instructive data accumulated regarding the mitochondrial diversity and maternal background of these breeds. In this study, it is aimed to unveil the domestication history of the goat and to explain the mtDNA diversity and phylogeographic structure of these breeds. For this purpose, D-loop and cytochrome $b$ regions was sequenced and analyzed from the Angora, Honamli, Kilis, Hair and Norduz goat breeds.

\section{Materials and Methods}

Sampling and DNA isolation procedures: A total of 252 blood samples of goats were collected from 5 Turkish native goat breeds on the natural habitat (Figure 1). To represent the genetic diversity in a reliable manner, samples from the breeds have been collected from subjects of distant zones, which are not bloodrelated. Gender and breed properties have been taken into consideration and geographical locations have also been properly recorded. After sampling procedure, mtDNA was extracted by phenol/chloroform method as described previously (Sambrook et al., 1989) and extracted DNA concentrations were adjusted to $50-100 \mathrm{ng} / \mu \mathrm{L}$ for PCR amplification.

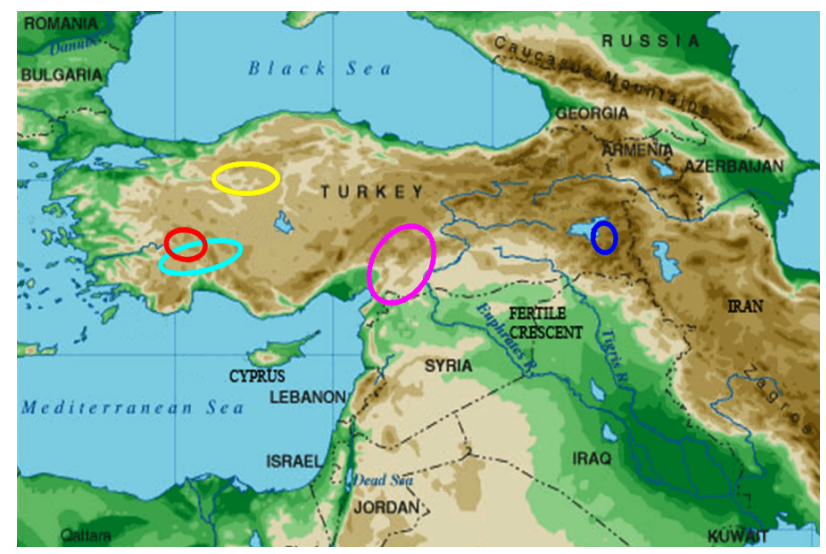

Figure 1. The localization of sampled provinces in the geographical Turkey map; yellow circle is Angora, red circle is Honamli, pink circle is Kilis, blue circle is Norduz goat breeds. Şekil 1. Türkiye fiziki haritası üzerinde örnekleme bölgelerinin konumları (Ankara sarı, Honamlı kırmızı, Kıl turkuaz, Kilis pembe ve Norduz mavi daire ile gösterilmiştir).

Amplification and sequencing: The complete Dloop was amplified by using forward primer Typing-2-F and reverse primer Typing-1-R (Sultana et al., 2003).
PCR was performed in a $25 \mu$ reaction mixture containing $100 \mathrm{ng}$ of genomic DNA, $2 \mathrm{mM} \mathrm{MgCl}_{2}, 5$ pmol of each primer, $200 \mu \mathrm{M}$ of each dNTP, 1U Taq DNA polymerase (MBI Fermentas) and 1X PCR buffer (10 mM Tris- $\mathrm{HCl}, \mathrm{pH} 9,0 ; 50 \mathrm{mM} \mathrm{KCl}$ ) by using Mastercycler thermal cycler (Eppendorf AG, USA) under the following conditions: first denaturation for $4 \mathrm{~min}$ at $94^{\circ} \mathrm{C}$ followed by 30 cycles of $30 \mathrm{~s}$ denaturation at $94^{\circ} \mathrm{C}$, $30 \mathrm{~s}$ primer annealing at $64^{\circ} \mathrm{C}$ and $70 \mathrm{~s}$ extension at $72^{\circ} \mathrm{C}$ with final extension $15 \mathrm{~min}$ at $70^{\circ} \mathrm{C}$. The PCR products were run through $2 \%(\mathrm{w} / \mathrm{v})$ agarose gel electrophoresis under $120 \mathrm{~V}$ for $20 \mathrm{~min}$ and then amplicons were purified on spin columns according to the manufacturer's instructions (QIAquick PCR Purification Kit, Qiagen). Two internal primers (CAP-F and CAP-R) including Hypervariable region-1 (HV-1) were used for sequencing as previously described by Naderi et al (2007).

Within each breed, cytochrome $b$ regions were amplified by L14724V and Chir_Cyto1R primers to the samples classified to different haplogroups based on their D-loop regions, in order to further investigate the introgression time. Amplifications with the outer primers have been performed under the same conditions and chemical concentrations mentioned above except for the annealing temperature to be $59^{\circ} \mathrm{C}$. Table 1 summarizes the used primers and their nucleotide sequences. Following the PCR purifications, all PCR products were sequenced directly on both strands by using an ABI 3130 autoanalyzer (Applied Biosystems, Foster City, CA, USA).

Table 1. Sequences of the used primers.

Tablo 1. Kullanılan primerlere ait diziler.

\begin{tabular}{|c|c|c|}
\hline Region & Primer & Sequence, $5^{\prime} \rightarrow 3^{\prime}$ \\
\hline \multirow{4}{*}{ D-loop } & Typing-2-F & $\begin{array}{l}\text { CCTCACTATCAGCACC } \\
\text { CAAAG }\end{array}$ \\
\hline & CAP-F* & $\begin{array}{l}\text { CGTGTATGCAAGTACA } \\
\text { TTAC }\end{array}$ \\
\hline & CAP-R* & $\begin{array}{l}\text { CTGATTAGTCATTAGT } \\
\text { CCATC }\end{array}$ \\
\hline & Typing-1-R & $\begin{array}{l}\text { CTACAATTTATGCTCC } \\
\text { GGGTC }\end{array}$ \\
\hline \multirow{6}{*}{ Cytochrome $b$} & L14724V* & $\begin{array}{l}\text { ATGATATGAAAAACCA } \\
\text { TCGTT }\end{array}$ \\
\hline & Chir_CytolintF*,+ & $\begin{array}{l}\text { CCTCCTGCTCGCAACA } \\
\text { ATGG }\end{array}$ \\
\hline & Chir_CytolintR ${ }^{*,+}$ & $\begin{array}{l}\text { ATGGGATTGCTGAAAG } \\
\text { AAGA }\end{array}$ \\
\hline & Chir_Cyto2intF*,+ & $\begin{array}{l}\text { TACTATTCACACCCGA } \\
\text { CCTA }\end{array}$ \\
\hline & Chir_Cyto2intR ${ }^{*,+}$ & $\begin{array}{l}\text { TTGGGGATTGATCGTA } \\
\text { GGATT }\end{array}$ \\
\hline & Chir_Cyto1R*,+ & $\begin{array}{l}\text { GGCTATTCTCCTTTTCT } \\
\text { GGTT }\end{array}$ \\
\hline
\end{tabular}

* Primers used for sequencing; ${ }^{+}$Primers designed in the present study.

*Dizi analizinde kullanlan pimerler; ${ }^{+}$yeni tasarlanan primerler. 
Data and phylogenetic analyses: The nucleotide sequences were aligned and edited by using BioEdit Version7.0.9.1 (Hall, 1999). Gaps in the aligned sequences were excluded from the following analyses. Further analyses were performed using 453bp for D-loop region and $1148 \mathrm{bp}$ for cytochrome $b$ region. The polymorphisms in the analyzed regions, nucleotide diversity $(\pi)$, haplotype diversity $(h)$ and their standard deviation values for the breeds were estimated by using DnaSP v5 software (Librado and Rozas, 2009). Maximum-likelihood (ML) tree was created by using PhyML v3.0 (Guindon and Gascuel 2003) with GTR model and aLRT test. To identify possible phylogenetic clades, Neighbor-Joining (NJ) tree was firstly constructed by using K2P model with pairwise deletion (1,000 replicates) with MEGA 4.0 software (Kumar et al., 2008) and classified to the clades according to the reference sequences described previously by Naderi et al. (2007). Since mtDNA is a haploid, differentiation between populations was assessed by sequence-based $\mathrm{F}$ statistics using MEGA 4.0 (Kumar et al., 2008) and distances tree was constructed with PHYLIP 3.69 (Felsenstein, 2005) and TreeView (Page, 1996) softwares. The statistical significance of the correlation between geographic and genetic distance matrices based on mtDNA data between breeds, was evaluated by the Mantel test and additionally, AMOVA statistics were used to show the hierarchical proportions of variance. Both analyses were performed by using Arlequin ver3.5.1.2 (Excoffier and Lischer, 2010). D-loop region sequences of $C$. aegagrus (EF989163, EF989426) (Naderi et al., 2008), C. caucasica (AJ317875), $C$. sibirica (AJ317874), C. cylindricornis (AJ317870), C. nubiana (AJ317871) and C. falconeri (AJ317872) (Luikart et al., 2001) and O. aries (AM279285) (Fajardo et.al., 2007) as an out group were used in order to enlighten the relation with wild goat.

Population history: A Median-joining network was generated to further investigate the possible relationships among the lineages by the program Network v.4.516 (Bandelt et al., 1999) to visualize the relationships among haplotypes of all samples. To test the neutral theory, DnaSP v5 was used (Librado and Rozas, 2009) to calculate Tajima's D (Tajima, 1989) and Fu's Fs (Fu, 1996). Cytochrome $b$ was used to estimate the molecular clock and the Time to Most Recent Common Ancestor, TMRCA. For this purpose, Minimum Evolutionary Tree was constructed by using the sequence of samples from different haplogroups and $O$. aries under MEGA 4.0 (Kumar et al., 2008) program and Maximum Composite Likelihood method. Nei's method ( $D=2 u r t)$ was used to estimate the age of the phylogenetic clades.

mt-lineage typing: In this study the new mt-lineage typing for $\mathrm{G}$ haplogroup was described by using a PCR restriction fragment length polymorphism (PCR-RFLP) method based on $\mathrm{A} \rightarrow \mathrm{G}$ transition at nucleotide position 16071 in the D-loop (A16071G). A specific segment of mtDNA was amplified using outer D-loop region primers. The amplified DNA was digested overnight at $37^{\circ} \mathrm{C}$ with the Bsp681 (NruI) (MBI Fermentas). Products were run on $2 \%$ agarose gel.

\section{Results}

Structure of the populations: Statistical data regarding the mtDNA diversity in studied breeds is shown in Table 2. A total of 208 haplotypes were identified within 252 goat samples and 174 of them were unique. Duplication insertions (77bp) observed on D-loop regions of two individuals from different breeds were quite remarkable.

Phylogenetic relations of the individuals were investigated by $\mathrm{NJ}$ and ML tree constructions assuming a gamma distribution parameter of $\alpha=0,349$ and the individuals were classified to haplogroups by the means of reference sequences (Figure 2). Based on these analyses, 245 of the animals were classified in Haplogroup A, which is thought to be the oldest haplogroup. Similarly, an Angora, a Kilis and four Honamli goats were classified in Haplogroup G and one Kilis goat is classified in Haplogroup D. One of the Kilis goats from Haplogroup D was identified on the same branch with a C. aegagrus (EF989426) and a Kilis and Hair goat from Haplogroup A were identified on the same branch with another C. aegagrus (EF989163) (Figure 2).

Table 2. Some statistical highlights about the studied breeds.

Tablo 2. İncelenen rrklarla ilgili bazı istatistiki değerler.

\begin{tabular}{lcccccc}
\hline Breed & $\mathrm{N}$ & $\mathrm{Nh}$ & $\mathrm{h} \pm \mathrm{sd}$ & $\pi \pm \mathrm{sd}$ & Fu's $F s$ & Tajima's $D$ \\
\hline Angora & 50 & 42 & 0,$993 ; \pm 0,005$ & 0,$0202 ; \pm 0,00162$ & $-32,968$ & $-1,57723^{*}$ \\
Honamli & 49 & 42 & 0,$993 ; \pm 0,006$ & 0,$0233 ; \pm 0,00187$ & $-29,266$ & $-1,25471$ \\
Kilis & 51 & 48 & 0,$998 ; \pm 0,004$ & 0,$0205 ; \pm 0,00188$ & $-47,991^{*}$ & $-1,85794^{* *}$ \\
Hair & 53 & 48 & 0,$996 ; \pm 0,005$ & 0,$0203 ; \pm 0,00108$ & $-44,975$ & $-1,46930$ \\
Norduz & 49 & 36 & 0,$983 ; \pm 0,008$ & 0,$0192 ; \pm 0,00101$ & $-20,170$ & $-1,30735$ \\
\hline Total & 252 & 208 & 0,$9982 ; \pm 0,0006$ & 0,$0210 ; \pm 0,00073$ & & \\
\hline
\end{tabular}

${ }^{*}, \mathrm{P}<0,10 ;{ }^{* *}, \mathrm{P}<0,05$

$\mathrm{N}$ : Number of sampled individuals, Nh: Number of haplotypes, h: Haplotype diversity, sd: Standart deviation, $\pi$ : Nucleotide diversity. N:Örneklenen birey sayısı, Nh: Haplotip sayısı, h: Haplotip çeşitliliği, sd: Standart sapma, $\pi$ : Nükleotit çeşitliliği. 


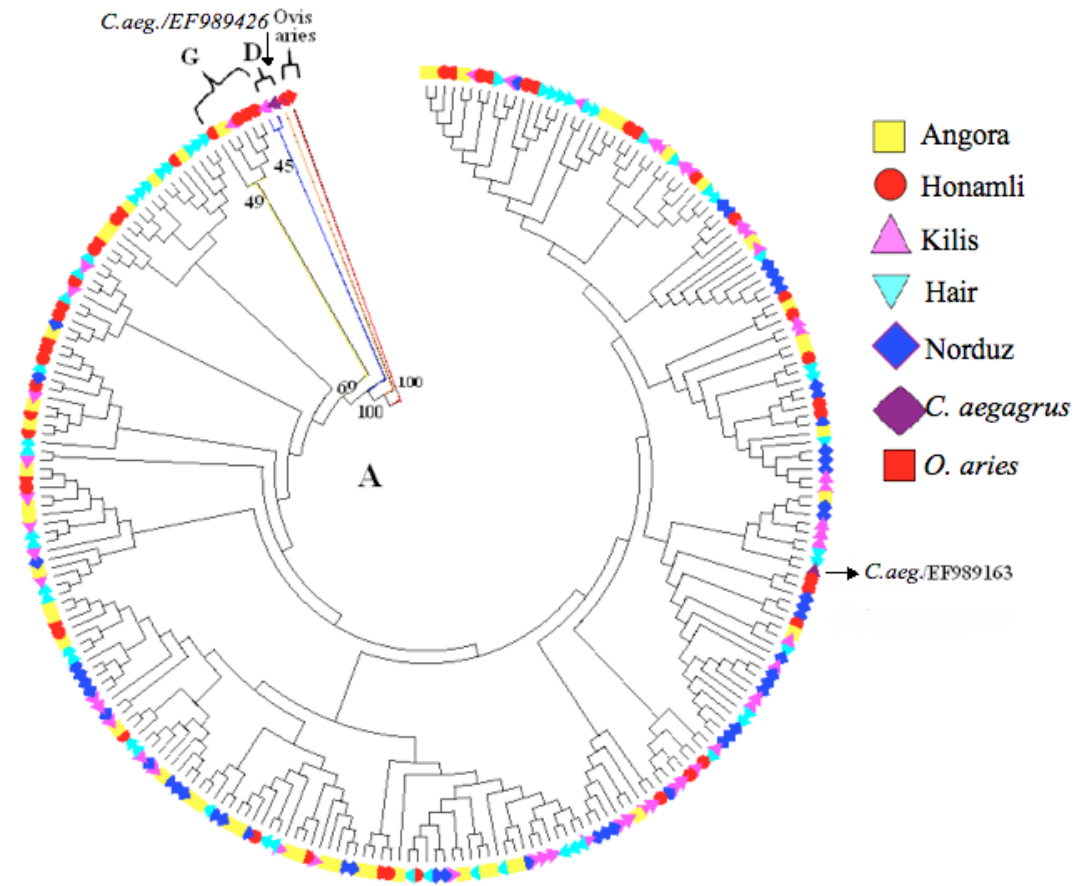

Figure 2. Maximum Likelihood tree of 252 individuals constructed under GTR model and aLRT test. Şekil 2. GTR modeli ve aLRT testi kullanılarak oluşturulan ML ağac1.

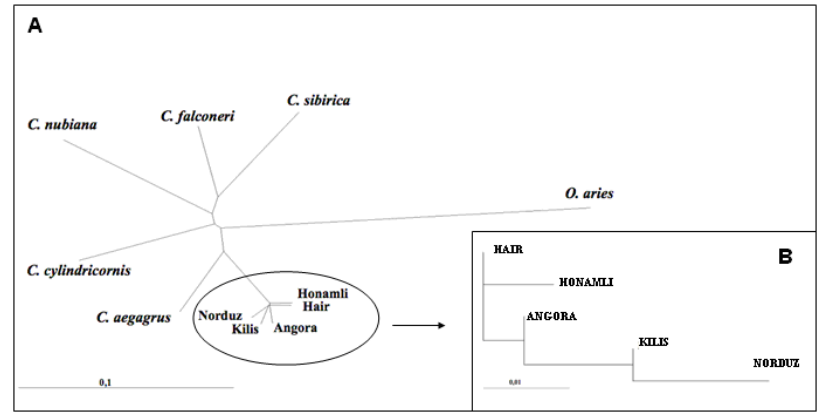

Figure 3. A. NJ tree constructed on $\mathrm{F}_{\mathrm{ST}}$ distances of all the breeds plus wild goats and $O$. aries as an out group. B. $\mathrm{NJ}$ tree of $\mathrm{F}_{\mathrm{ST}}$ distances of the studied breeds only.

Şekil 3.A.Tüm rrklar, yaban keçileri ve diş grup olarak koyun kullanılarak $F_{\text {ST }}$ uzaklıklarına gore NJ ağacı. B. Sadece incelenen ırklara ait $\mathrm{F}_{\mathrm{ST}}$ uzaklığı için $\mathrm{NJ}$ ağacı.

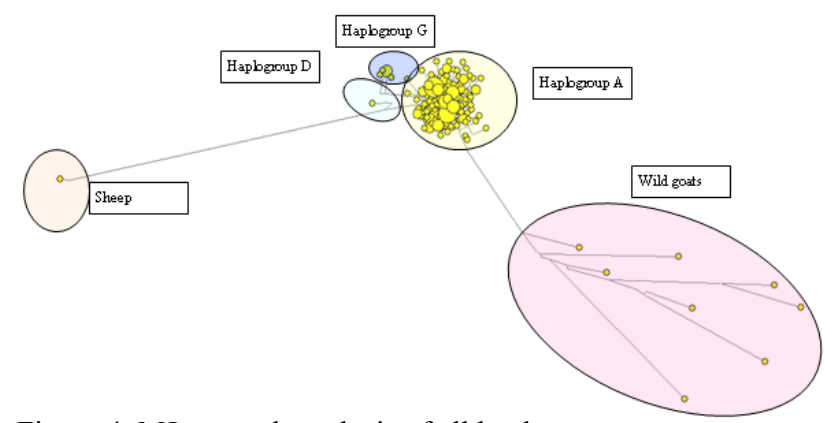

Figure 4. MJ network analysis of all haplotypes.

Şekil 4. Tüm haplotiplere ait Median-Joining networkü.

According to pairwise $\mathrm{F}_{\mathrm{ST}}$ distances, all breeds have been involved on the same branch with $C$. aegagrus (Figure 3.A). Pairwise $\mathrm{F}_{\mathrm{ST}}$ comparisons also showed that there is a low genetic differentiation between Hair and
Honamli goats and likewise between Kilis and Norduz goats. Norduz and Honamli goats have also a mild genetic differentiation between each other. $(0,045$; $\mathrm{p}<$ 0,001) (Figure 3.B). All phylogenetic trees demonstrated similar branching patterns for breeds and analyzed data showed that a breed-specific localization or distribution was not present.

To estimate the correlation between geographic and genetic distances matrices an experimental setup in which Kilis and Norduz goats were considered in the same group, Honamli and Hair goats were considered in another and Angora breed was considered as a separate group was designed. In this particular design, $\Phi_{\mathrm{CT}}$ value was estimated quite high $(71,15)$ (data not shown). According to Mantel test results, a strong relation $(0,75$; $\mathrm{p}<0,05)$ between geographic and genetic distances was observed.

History of the populations: Fu's Fs and Tajima's $D$ values are provided on Table 3. Median Joining network obtained from haplotypic data showed that all haplotypes condensed around a centric area, each sequence represented almost a specific haplotype and Haplogroup A has a star-like pattern (Figure 4). The TMRCA based on cytochrome $b$ distances for Haplogroups A, D and G was calculated to be 168,000 years and $G$ was found to be the oldest haplogroup among all. For the determination of this haplogroup, a novel method was introduced. In this wise, two segments with 691 and 311 bp were harvested via an enzymatic digestion process of a 1002 bp D-loop region obtained by amplification with outer primers (Figure 5). 


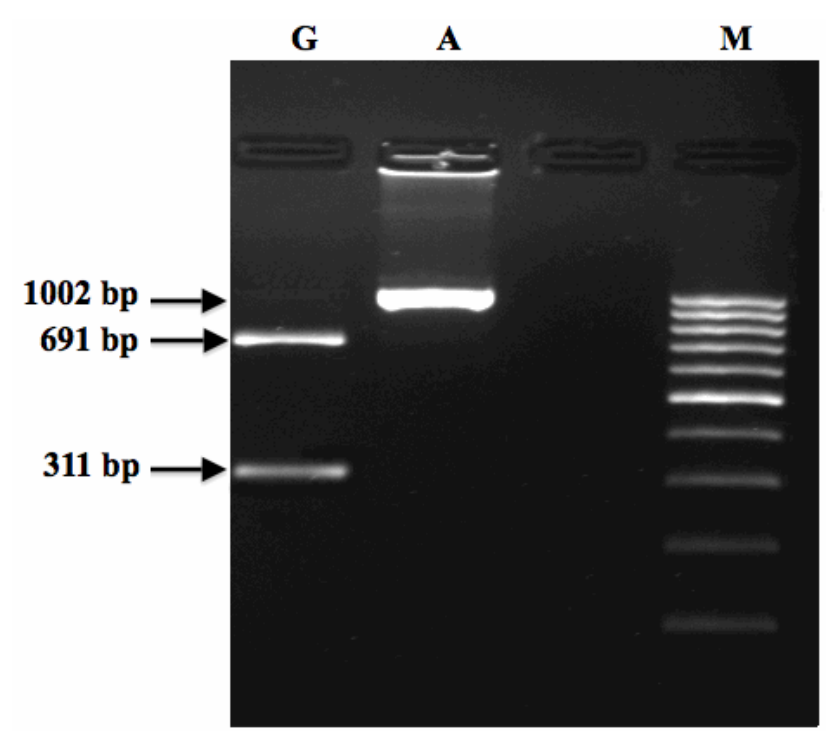

Figure 5. The PCR-RFLP analysis for typing Haplogroup G. Lane $\mathrm{G}$ is Haplogroup G, Lane A is Haplogroup A and Lane M is 100bp DNA ladder (MBI Fermentas).

Şekil 5. G-haplogrubu belirlemede PCR-RFLP analizi. G sıras1 $\mathrm{G}$ haplogrubunu, A siras $\mathrm{A}$ haplogrubunu, $\mathrm{M}$ siras ise 100bp DNA ladderi (MBI Fermentas) göstermektedir.

\section{Discussion and conclusion}

Domestic goat (C. hircus) is thought to originate from wild goat species C. aegagrus, C. falconeri, $C$. prisca, C. ibex and C. caucasica with respect to their horn morphology and distribution profile (Batu, 1951). In the present study; our results demonstrated that 5 of the Turkey's native goat breeds originated from $C$. aegagrus (bezoar), in accordance with the findings of Mannen et al. (2001). C. prisca is an extinct group, so we did not have the chance of a molecular comparison for this specie. It is of particular interest that two members of Kilis breed from Fertile Crescent region have highly similar sequence profile with two wild goats, thus, possessing ancient haplotypes.

Two of the main factors to determine the domestication zones are nucleotide and haplotide diversity. In circumstances where selection and isolation is ruled out, diversity is expected to reduce as distance from the domestication zone increases, since, groups which are being moved out of the genetic pool could only carry a limited number of genotypes (Loftus et al., 1999; MacHugh and Bradley, 2001). The estimated diversity indices suggest that Kilis goat breed exhibits the highest diversity. In terms of nucleotide and haplotype diversity, except for Norduz goat breeds, all groups show high values as compared with mainly world goat breeds (Luikart et al., 2001; Joshi et al., 2004; Pereira et al., 2005; Naderi et al., 2007). This finding indicates a central localization for Turkey in the goat domestication course, in accordance with the findings of Naderi et al. (2008).
A, D and $\mathrm{G}$ haplogroups have been determined in 5 breeds studied. Haplogroups B and C, often recognizable in Asian countries, were not found in this study. This can be attributable to introgression times and human migration routes. Based on the assumption that Angora goat breed have been transported from Central Asia (Akçapınar, 1994), one can speculate that these haplogroups could have been introduced to the population at a later time zone than the migration of Angora goats' ancestors from Central Asia to Anatolia, or, ancestor lineages of Central Asia could have deceived their B and C haplogroups after their arrival at Anatolia. Based on neutrality test findings, Kilis goat breed seems to have an expansion of population and accretion of new, low frequency haplotypes. However, when considered that Kilis and Norduz breeds do not share a common haplotype with Hair goat breed, the claim that these breeds are Hair goat crossbreeds (Yalçın, 1986; Porter, 1996), may need a further ascertainment in terms of breed backgrounds. Additionally, our results indicated that Haplogroup $G$ is the most ancient haplogroup for Turkish native goat breeds and oldest haplogroup used in the domestication course was Haplogroup A. Besides, a novel, cost and time-effective method for the determination of Haplogroup G is introduced in this study.

Inbreeding and mating with culture breeds, yield to vanishing of the native breeds. Despite their low delivery profile, the loss of native breeds, given their adaptability features acquired throughout thousands of years via natural selection such as resistance to illnesses and adaptation capabilities to ambient conditions, is of quite importance to genetics. This data showed that the studied breeds preserved their mtDNA diversities. However, these results should be further analyzed using alternative molecular markers and comparisons, in order to construct new preservation strategies accordingly. Furthermore, collaboration with other scientists such as archeologists and a providing a multidisciplinary perspective is a must for the accurate determination of time points in the assessment of population history.

\section{Acknowledgements}

The authors wish to thank TURKHAYGEN-1 (In Vitro Conservation and Preliminary Molecular Identification of Some Turkish Domestic Animal Genetic Resources-I; KAMAG-106G005) Project staff.

\section{References}

1. Akçapınar H (1994): Keçi Yetiştiriciliği Ders Notları. Ankara Üniversitesi Veteriner Fakültesi Zootekni Anabilim Dal1.

2. Bandelt HJ, Forster P, Röhl A (1999): Median-joining networks for inferring intraspecific phylogenies. Mol Biol Evol, 16, 37-48. 
3. Batu S (1951): Türkiye Yerli Keçi Irkları ve Keçi Yetiştirme Bilgisi. Ankara Üniversitesi Veteriner Fakültesi Kitab1 No:2.

4. Excoffier L, Lischer HEL (2010): Arlequin suite ver 3.5: A new series of programs to perform population genetics analyses under Linux and Windows. Mol Ecol Resour, 10, 564-567.

5. Fajardo V, Gonzalez I, Lopez-Calleja I, Martin I, Rojas M, Pavon MA, Garcia T, Hernandez PE, Martin R (2007): PCR identification of meats from chamois (Rupicapra rupicapra), pyrenean ibex (Capra pyrenaica), and mouflon (Ovis ammon) targeting specific sequences from the mitochondrial D-loop region. Meat Sci, 76, 644652.

6. Felsenstein J (2005): PHYLIP version 3.6. Distributed by the author. Department of Genome Sciences, University of Washington, Seattle.

7. Fu YX (1997): Statistical tests of neutrality of mutations against population growth, hitchhiking and background selection. Genetics, 147, 915-925.

8. Guindon S, Gascuel O (2003): A simple, fast, and accurate algorithm to estimate large phylogenies by maximum likelihood. Syst Biol, 52, 696-704.

9. Hall TA (1999): BioEdit:a user-friendly biological sequence alignment editor and analysis program for Windows 95/98/NT. Nucl Acids Symp, 41, 95-98.

10. Joshi MB, Rout PK, Mandal AK, Tyler-Smith C, Singh L, Thangaraj K (2004): Phylogeography and origin of Indian domestic goats. Mol Biol Evol, 21, 454-462.

11. Kumar S, Dudley J, Nei M, Tamura K (2008): MEGA: A biologist-centric software for evolutionary analysis of DNA and protein sequences. Brief Bioinform, 9, 299-306.

12. Librado P, Rozas J (2009): DnaSP v5: A software for comprehensive analysis of DNA polymorphism data. Bioinformatics, 25, 1451-1452.

13. Loftus RT, Ertugrul O, Harba AH, El-Barody MA, Machugh DE, Park SD, Bradley DG (1999): $A$ microsatellite survey of cattle from a centre of origin: the Near East. Mol Ecol, 8, 2015-2022.

14. Luikart G, Gielly L, Excoffier L, Vigne J-D, Bouvet J, Taberlet P (2001): From the Cover: Multiple maternal origins and weak phylogeographic structure in domestic goats. PNAS, 98, 5927-5932.

15. MacHugh DE, Bradley DG (2001): Livestock genetic origins: Goats buck the trend. PNAS, 98, 5382-5384.

16. Mannen H, Nagata Y, Tsuji S (2001): Mitochondrial DNA reveal that domestic goat (Capra hircus) are genetically affected by two subspecies of Bezoar (Capra aegagrus). Biochem Genet, 39, 145-454.
17. Naderi S, Rezaei HR, Taberlet $\mathbf{P}$, Zundel S, Rafat SA, Naghash HR, Elbarody MAA, Ertugrul O, Pompanon F (2007): Large-scale mitochondrial DNA analysis of the domestic goat reveals six haplogroups with high diversity. PLoS ONE, 2,10, e1012.

18. Naderi S, Rezaei HR, Pompanon F, Blum MG, Negrini R, Naghash HR, Balkiz O, Mashkour M, Gaggiotti OE, Ajmone-Marsan $\mathbf{P}$, Kence A, Vigne JD Taberlet $\mathbf{P}$ (2008): The goat domestication process inferred from large-scale mitochondrial DNA analysis of wild and domestic individuals. PNAS, 105, 17659-17664.

19. Pereira F, Pereira L, Van Asch B, Bradley DG, Amorim A (2005): The mtDNA catalogue of all Portuguese autochthonous goat (C. hircus) breeds: high diversity of female lineages at the western fringe of European distribution. Mol Ecol, 14, 2313-18.

20. Porter V (1996): Goats of the World. Farming Press, Ipswich, UK.

21. Sambrook J, Fritsch EF, Maniatis T (1989): Molecular Cloning: A Laboratory Manual, vol. I., $2^{\text {nd }}$ edition. Cold Spring Harbor Laboratory Press.

22. Sultana S, Mannen H, Tsuji S (2003): Mitochondrial DNA diversity of Pakistani goats. Anim Genet, 34, 417421.

23. Tajima F (1989): Statistical method for testing the neutral mutation hypothesis by DNA polymorphism. Genetics, 123, 585-595.

24. Wu YP, Guan WJ, Zhao QJ, He XH, Pu YB, Huo JH, Xie JF, Han JL, Rao SQ, Ma YH (2009): A fine map for maternal lineage analysis by mitochondrial hyperviable region in 12 Chinese goat breeds. Anim Sci J, 80, 372380.

25. Yalçın BC (1986): Sheep and Goats in Turkey. FAO Animal Production and Health Paper, 60.

26. Zeder MA (2008): Domestication and early agriculture in the Mediterranean Basin: Origins, diffusion, and impact. PNAS, 19, 11597-11604.

Geliş tarihi: 27.10.2010 / Kabul tarihi: 29.11.2010

Addres for correspondence:

Bengi Çınar Kul, DVM, PhD

Department of Genetics,

Faculty of Veterinary Medicine, Ankara University,

Ankara 06110, Turkey.

Phone: 903123170315 ext: 314

E-mail:bkul@veterinary.ankara.edu.tr 